\title{
Spirit Possession and Healing in Modern Zambia: An Analysis of Letters to Archbishop Milingo
}

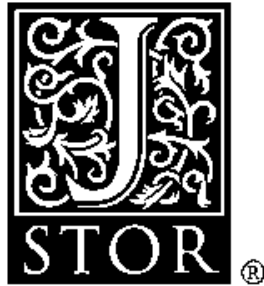

Gerrie ter Haar; Stephen Ellis

African Affairs, Vol. 87, No. 347. (Apr., 1988), pp. 185-206.

Stable URL:

http://links.jstor.org/sici?sici=0001-9909\%28198804\%2987\%3A347\%3C185\%3ASPAHIM\%3E2.0.CO\%3B2-M

African Affairs is currently published by Oxford University Press.

Your use of the JSTOR archive indicates your acceptance of JSTOR's Terms and Conditions of Use, available at http://www.jstor.org/about/terms.html. JSTOR's Terms and Conditions of Use provides, in part, that unless you have obtained prior permission, you may not downIoad an entire issue of a journal or multiple copies of articles, and you may use content in the JSTOR archive only for your personal, non-commercial use.

PIease contact the publisher regarding any further use of this work. Publisher contact information may be obtained at http:/www.jstor.org/journals/oup.htmI.

Each copy of any part of a JSTOR transmission must contain the same copyright notice that appears on the screen or printed page of such transmission.

ISTOR is an independent not-for-profit organization dedicated to creating and preserving a digital archive of scholarly journals. For more information regarding ISTOR, please contact support@jstor.org. 


\title{
SPIRIT POSSESSION AND HEALING IN MODERN ZAMBIA: AN ANALYSIS OF LETTERS TO ARCHBISHOP MILINGO
}

\author{
GerRie Ter HAar AND STEPHEN Eli.is
}

ThIS ARTICLE is based on research carried out into the healing ministry of Monsignor Emmanuel Milingo, who was the Roman Catholic Archbishop of Lusaka, Zambia from 1969 to 1983 . $^{1}$ At the time of his appointment to the see of Lusaka by Pope Paul VI, it was evident that Archbishop Milingo represented a rather new departure in the affairs of the Zambian Church. In particular, he was the first African to hold the important see of Lusaka, a fact which generally attracted the approval of Zambian nationalists and those in the Church at large who were in favour of greater Africanisation. He was also rather young for such a senior post. Emmanuel Milingo was born in 1930 of a poor farming family in Zambia's Eastern Province, close to the border with what is now Malawi. During his childhood he worked as a cowherd, looking after his father's cattle, until he took the decision at the age of 12 to secure an education, when he left home and enrolled at a local school which had recently been established by the White Fathers. It appears that only after entering the minor seminary some two years later did the idea of training for the priesthood gradually take precedence over the desire to receive a general education. In this he was strongly supported by his family which played an active role in the realisation of his vocation.

In December 1965, only a year after Zambia had become an independent state, Father Milingo, as he then was, was transferred to Lusaka to work for the Zambian Episcopal Conference (ZEC) as a secretary to the Department of Mass Media. Through his work as a broadcaster with the ZEC Milingo showed a talent for mass communication. He also showed an interest in working with the poorest people in the city, notably by organising medical work in the teeming townships and slums of the capital.

\footnotetext{
Gerrie ter Haar, who conducted field work in Zambia for four months in 1986, teaches at the University of Utrecht. Stephen Ellis is a political analyst and research associate of the School of Oriental and African Studies, University of London. They are grateful to Professor J. M. Schoffeleers, Professor Gerrit Huizer, Dr J. G. Platvoet and Dr David Lan for their comments.

1. Gerrie ter Haar is preparing a doctoral thesis on the healing ministry of Archbishop Milingo. This is part of a collective research project into the pastoral role of the nganga in Africa under the direction of Professor Schoffeleers at the Free University of Amsterdam. Financial assistance for her field work was provided by the Netherlands Foundation for the Advancement of Tropical Research (WOTRO).
} 


\section{The healing ministry}

So, by the time Milingo was appointed to the archbishopric of Lusaka, he was already well-known to the citizens of Zambia's capital city. But it was only after 1973 that he also gained a reputation as a spiritual healer. According to Milingo himself, this occurred after a woman had consulted him about her baby whom, although physically healthy, she persistently regarded as non-human and of whom she was frightened. ${ }^{2}$ The archbishop tried by all pastoral means to help her, only to see his efforts fail. When she came back to him he felt powerless. As he himself described it,

At that time I didn't know how Satan behaves once he is in possession of someone. I contemplated various ways of helping the woman when suddenly an idea glowed in my mind: "look three times intently into her eyes and ask her to look three times intently into yours. Tell her to close her eyes the third time and order her to sleep. Then speak to her soul after signing her with the sign of the cross."

The woman was subsequently made well, and Archbishop Milingo became convinced that God had given him the gift of healing through the power of the Holy Spirit. 'I experienced the power of the Holy Spirit on 13th April, 1973. From then on I discovered that I could help thousands and thousands of people under obsession or bondage of evil spirits'. ${ }^{4}$ Shortly afterwards, he publicly proclaimed at his cathedral in Lusaka's Roma township that God had endowed him with the gift of healing, and that those who suffered from evil spirits commonly known as mashave ${ }^{5}$ and who had previously sought spiritual healing from healers outside the Church, or who had suffered in silence, should henceforth put their faith in the Church. He declared that the Holy Spirit had powers greater than those of the evil spirits and could heal people who were sick in spirit. 'So', he told his congregation, 'if any of you suffer from this disease, let them come forward and we shall try to help them' ${ }^{6}$ Archbishop Milingo has always maintained that there is clear Biblical authority for this belief in the Church's healing ministry, and he quotes in support of this Christ's specific injunction to His apostles to preach the Gospel, to heal the sick and to cast out demons. ${ }^{\text {? }}$

During the years after 1973, Archbishop Milingo began to hold frequent public healing sessions. He became a household name throughout Zambia and famous in other parts of English-speaking Africa too. He gained a reputation as a successful healer and as a man of great saintliness. People possessed by evil spirits or related ills sought his attention at his official

2. E. Milingo, Healing: 'If I tell you, you will nor believe me!' (Lusaka, 1976), p. 1.

3. Milingo, Healing, p. 1 .

4. Private document.

5. We are using this spelling of mashave in this article. There are other variants of the spelling.

6. Milingo, Healing, p. 2.

7. Milingo, Healing, p. 25. 
residence in Roma, or indeed wherever they could find him. However, the time he spent in healing and other pastoral work detracted from the performance of his considerable administrative duties as head of the archbishopric. Throughout this period, but especially after 1978, his tenure of the Lusaka archbishopric and his healing ministry attracted much controversy. In April 1982, Milingo was therefore summoned to the Vatican after a papal investigation. His departure from Zambia was widely reported in both the Zambian and the international press. He resigned as Archbishop of Lusaka in 1983 and since then has held office in the Vatican as a special delegate to the Papal Commission for Migration and Tourism. His duties there include the pastoral care of refugees in Africa. ${ }^{8}$ He has visited Zambia twice since 1982.

\section{The letters to Milingo}

Archbishop Milingo's career and his vocation to heal the sick through the power of the Holy Spirit have important implications for theology and Church politics. ${ }^{9}$ However, the present article is rather more secular in scope. During the course of research into the wider implications of Milingo's healing ministry, we had access to a collection of some 250 letters written to the Archbishop in 1979 and 1980 by people in need of spiritual healing or guidance. The vast majority clearly believed themselves to be possessed by evil spirits and petitioned the Archbishop in the belief that he could heal them. ${ }^{10}$

Without doubt, these letters are only a small proportion of those received by Milingo during this period. They are contained in two files which appear to have formed an archive of a more extensive number of requests for healing and do not include his usual administrative or other correspondence. One file dates mostly from early 1979 and the other from mid-1980. Given that the 250 letters form only an incomplete record of the petitions received by Milingo during a period of some 20 months, it is evident that he was in fact receiving several letters on the subject every week, if not every day. This is apart from the dozens of people who used to visit Milingo's residence daily at this time to seek an audience, but without submitting any written request.

However, it is hardly necessary to demonstrate the popularity of Archbishop Milingo's healing ministry since those who remember it are unanimous in describing how hundreds, or even thousands, of people would

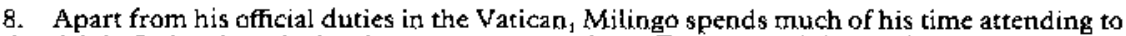
the sick in Italy where he has becorre very popular. Every month he holds a public healing mass in Rome.

9. Throughowt the article, references to the Church should be taken to mean the Roman Catholic Church, either in Zambia or generally.

10. These letters were made available to us by a private source. Archbishop Milingo has given us permission to use the letters and has read a draft of the present article. 
attend his public healing sessions. Observers also emphasise that his activities excited wider interest among Zambians of all social classes. He was the focus of the most important religious revival seen in Zambia since the decline of Alice Lenshina's Lumpa Church, which was forcibly suppressed in 1964. There are even those who have suggested that, largely as a result of his healing ministry, Milingo became one of the best-known Zambians of his day, second only to President Kenneth Kaunda.

The main interest of the letters to Milingo, from a secular point of view, is that they provide a first-hand account of an intimate area of people's lives. ${ }^{11}$ The petitions provide an opportunity to discover, in their own words, the ideas of those who believe themselves possessed. They form a valuable documentary record of the attitudes of ordinary Zambians towards the dominant problems in thcir lives. They are consequently of both social and political interest. Accordingly, we propose to identify the petitioners' social background, to analyze the contents of their letters, and, bearing in mind other information regarding the Archbishop's petitioners, to discuss the sociological and political implications of our findings. The existing literature on spirit possession generally, including in Zambia, often relates to the rural poor, tends to be based on descriptions by witnesses rather than on first-hand accounts, and frequently overlooks the political dimensions of spirit possession. ${ }^{12}$

It is likely that the number of written requests for healing made to Archbishop Milingo, as opposed to the number of oral requests, increased dramatically during 1979. Until February of that year the Archbishop was still holding public healing sessions in Lusaka, attracting on each occasion over $I, 000$ people seeking cures for their ills. As many as 4,000 attended Milingo's last healing session of this period on 25 February 1979. After this date he ceased holding regular public sessions, at the request of his fellow-bishops in Zambia and in compliance with the wish of the Vatican. Until then, many people seeking cures could attend the healing sessions in person and had little need to write to Milingo. However, the end of the regular public healing sessions did not dim the enthusiasm of the Zambian

11. Given the rarity of such material, we have chosen to write this article from the point of view of those who believe themselves possessed, basing our analysis on their beliefs. 'The only anthropologist whose work we know of who has based his research largely on correspondence from clients is A. P. Wendroft, Trouble-shooters and Trouble-makers: witch-finding and traditional Malatuian medicine (Ph.D. City University, New York, 1985). However, his research focusses on witchcraft rather than on spirit possession and therefore provides little information on this particular matter.

12. Most anthropological licerature on spirit possession tends to emphasise the social and psychic dimensions of this phenomenor. See e.g. I. M. Lewis, Ecstatic Keligion; an anthropological study of shamanism and spirit possession (Penguin Books, Harmondsworth, 1971 ); J. Beattie \& J. Middleton (eds.), Spirit Possession and Society in Africa (Routledge and Kegan Paul, London, 1969); E. Bourguignon (ed, ), Religian, Altered States of Consciousness, and Social Change (Ohio Stare University Press, Columbus, 1973); V. Crapanzano \& V. Garrison (eds), Case Studies in Spirit Possession (John Wiley \& Sons, New York, 1977). The basic work on spirit possession in Zambia is W. van Binsbergen, Religious Change in Zambia; exploratory siudies (In de Knipscheer, Haarlem, 1979). 
public for the Archbishop's ministry. People continued to seek audiences with Milingo in private, and he had to leave his house in Lusaka on occasion in order to comply with the bishops' request not to spend his time healing the sick. They felt that Milingo's role as a healer was inappropriate for his duties as an Archbishop and was not in conformity with the doctrine of the Church. After a series of articles about his powers in Zambian newspapers, some people came to believe that Milingo could heal the sick by correspondence or even by telephone as well as by the laying-on of hands. Accordingly, the tone of the letters addressed to Milingo during 1979 and 1980 changed noticeably. During 1979 he received a high proportion of letters commenting on the hierarchy's prohibition on public healing and begging the Archbishop to continue his public ministry. By 1980, the letters tended rather to be direct requests for healing by people who would previously have attended Milingo in person to seek his help.

\section{Healing and class}

The letters addressed to Archbishop Milingo in 1979-80, which constitute our sample, are probably not a representative cross-section of all those people who sought to be healed by him. By defunition, all the letters are from literate people. All but about ten of them are in English. According to UNESCO, 75 per cent of Zambian adults are literate. ${ }^{13}$ The letters of petition to Milingo may therefore represent only the more educated among his supplicants, the literate ones, and may not represent the views of the one Zambian in four who is illiterate. So it is also important to analyse the opinions contained in the letters in the light of oral testimony about the beliefs and behaviour of the other, less articulate, people who sought healing in the same period.

This in fact leads to an important point. It has often been suggested that Milingo's followers were mostly from the poorer and more deprived sections of society. That may be so, but the letters include dozens from teachers and business employees. Some are from graduates of the University of Zambia. One is from a senior executive of a bank in Tanzania, and there are traces of still more august supplicants. 'Today', Milingo wrote to a correspondent on 7 January 1980, 'I was on to the phone [to] one of these very responsible people in the Government, he too says that he wants to give testimony to the healing of his niece'. ${ }^{14}$ After Milingo's first visit to Zambia following his summons to Rome in 1982, one government minister (Ludwig Sondashi, then Minister for Social Affairs) openly stated that he had been healed by Milingo. And President Kaunda himself has publicly stated his support for Milingo's ministry on several occasions. Although

13. Africa South of the Sahara 1987 (Europa Publications, London, 1986), p. 1113.

14. Letter from Milingo dated 7 January 1980 to Miss $E$. $M$. in Lusaka. In order to respect the confidentiality of the letters we will only refer to correspondents by their initials. 
there is no evidence that President Kaunda shares any belief with Milingo beyond his Christianity, nor that he has ever sought the Archbishop's healing, the point is nonetheless made that Milingo's ministry was either respected or even supported at the highest levels of Zambian society. If it was overwhelmingly the poor who flocked to Milingo's house and cathedral in Roma township, it is also true that others attended to his message in different ways.

\section{Healing and Christianity}

Whether all the Archbishop's petitioners were equally Christian is harder to determine, since there appears to be no evidence regarding the religious affiliations of those who attended his public healing sessions. It is tempting to speculate that people who have attended school are more likely to be Christian than those who have not, since education and religion in Zambia are connected. Certainly, the letters to Milingo affirm that those who wrote to the Archbishop were overwhelmingly Christian. Numerous letters contain references to Jesus Christ or Biblical quotations. Many cite passages from the New Testament dealing with exorcism and healing. Some writers inform the Archbishop that they are Catholics, and others that they are members of the United Church of Zambia or another Protestant Church. Some admit to being lapsed or non-observing Christians. In one or two cases, they give a specific reason for this lapse, such as that they have become estranged from the Church due to its teaching on polygamy. These writers often express the hope that the Archbishop's healing might be the means of their being restored to full communion with the Church. On the whole, the letters permit little doubt that Milingo's literate supplicants were overwhelmingly Christian in at least a vague sense, while many profess to being active Church members. They consider Milingo, as he considers himself, to be a person endowed by God with special gifts to be used in the interest of suffering humanity. None seems to consider this a belief incompatible with Christianity and there is no suggestion that Milingo might in some way be a cult-leader or divinity himself.

This point, that Milingo is an ordinary human being endowed with special gifts by God, is discussed by correspondents with particular frequency after the bishops' prohibition on Milingo's public healing sessions in early 1979. Many writers express their indignation at such a decision, since Milingo is, as one writer put it, "our link between we sick people and Jesus Christ'. ${ }^{15}$ Almost invariably the line of argument used by the writers is to say that, since Milingo's gifts come from God, they must be good. Far from considering the Archbishop to have autonomous power, or to have received his power from some evil source, one correspondent even became

15. Letcer to Milingo from J. M., Mansa, 16 March 1979. 
so indignant as to suggest that Milingo's opponents within the Church are themselves the agents of the Antichrist. On 27 May 1980, this correspondent wrote from the town of Kafue:

I know there is pressure from the superiors so that you stop praying for the sick. I also understand that you would like to obey. I believe Satan uses every trick recorded in the book-even the superiors themselves can be used by the devil. He tempted the Lord Jesus Christ, the Son of God, and those superiors are just human beings-open and accessible to the devil. ${ }^{16}$

\section{Healing and urban life}

If Milingo's petitioners were modern in the sense of being overwhelmingly Christian, they were modern also in the sense of being mostly urban. Some letters specifically refer to traditional beliefs about spirit possession or witchcraft in the context of modern employment. There is, for example, the case of a 30-year old woman who had left her job at the United Bus Company of Zambia in Kitwe because she believed it to be infested by witches. ${ }^{17}$ Several writers are also troubled by the typically modern urban problem of unemployment. A man writing from Ndola in Zambia's Copperbelt on 9 July 1980 stated his problems to be bad luck and unemployment. He had lost his job in the copper mine at Chingola three years previously and had been unemployed ever since. As a result, his friends and relations had deserted him. 'Even my brother has turned away from me. Just because I am out of employment, he has even started denying me food'. He begs the Archbishop for his help and prayers, 'for the Lord has enlightened his powers to you to cure and save those in problems'. ${ }^{18}$ In fact the majority of letters are similarly from correspondents living in Zambia's main towns: Lusaka, the Copperbelt towns, and Kabwe. Few letters come from villagers.

Without doubt spirit possession is as likely to occur in towns as in the villages where it has existed since time immemorial. It is of course a truism to observe that the migration of country-dwellers to a harsh city life can be the cause of upheaval and changes in patterns of behaviour. This is especially so in central Africa which, unlike West Africa for example, had no indigenous tradition of city life before the present century. It is nonetheless striking, in reading the letters addressed to the Archbishop, to read at first hand of the hardship of modern life and its supposed relation to spirit possession. The spirit world is rarely absent from the letters.

Like most towns in the world, Zambia's urban centres are melting-pots where people of different geographic and ethnic origin, having various

16. Letter to Milingo from A. P., Kafue, 27 May 1980.

17. Letter to Milingo from Miss C. R. T., Kitwe, no date.

18. Letter to Milingo from S. K., Ndola, 9 July 1980. 
mother tongues, live cheek by jowl. People continue to identify themselves and others by ethnic labels on many occasions and many Zambians feel that ethnic identification is important especially in employment, when a company director is often believed to use favouritism in distributing jobs among his relatives or among people from his home region. Some people have also suggested that major towns like Lusaka have distinct ethnic neighbourhoods, one township being dominated by people from one part of the country. But many people in towns marry outside the lines proposed by rural tradition, and they tend to neglect some of the least important traditional languages in favour of the most widespread Zambian tongues, such as ci-Bemba and ci-Nyanja. Nevertheless, people retain a keen sensitivity to ethnic identification. ${ }^{19}$

\section{Healing and ethnicity}

A number of informants have suggested to us that this may have had some effect on the composition of Milingo's following. For example, one Catholic priest told us that, since Milingo used to preach in either English or ci-Nyanja (the dominant language of Lusaka), ci-Bemba-speakers were less attracted by his preaching than some other Zambians. Similarly, a traditional healer suggested to us that a disproportionately high number of Milingo's followers had their roots in Zambia's Eastern Province, like Milingo himself. Since the evil spirits known as mashave were believed to have originated in the east, it would follow that a healer from that region would be the appropriate person to consult in a case of possession by mashave. Although the precise history of mashave remains unclear, modern research suggests that they are indeed of foreign origin (Shona, in fact) and may even have their roots in Mozambique. Certain types of mashave are believed to have been transmitted to Zambia through the Southern and Eastern Provinces, possibly through the Ngoni people, who are an off-shoot of the Zulu. ${ }^{20}$ Milingo himself is Ngoni.

However, a study of petitioners' letters provides little evidence to support a theory that Milingo's preaching exercised an attraction which was in some respect ethnic or regional. Very few writers think it necessary to identify their area of origin or ethnic identity. In the great majority of cases the only way of identifying a writer's origin is by the family name--which may for example be distinctively Bemba, Tonga or Lozi-or by place of residence. The latter is in any case an inaccurate guide since so many writers are from the large industrial towns which contain Zambians of every ethnic origin.

19. These observations are based on interviews with Lusaka residents. Cf. Bennetta JulesRosette, Symbols of Change; urban transition in a Zambian community (Ablex, Norwood, New Jersey, 1981 ).

20. E. Colson, 'Spirit Possession among the Tonga of Zambia', in Beatric \& Middleton (eds), Spirit Possession, pp. 82-85 and 94-96; and $H$. Bücher, Sptrits and Power : an analysis of Shona cosmology (Oxford University Press, Cape Town, 1980), pp. 89-93. 
On the other hand, it is possible to identify some 40 writers out of the sample of 250 who write from the Chipata area of Eastern Province or whose names are typically eastern. This could suggest that there is some basis for the supposition that a relatively large number of Milingo's followers had some connection with his own Eastern Province, but the evidence is so weak as to be hardly worth regarding. Moreover Milingo himself never made any special appeal to his own tribesmen or even his own countrymen. On the contrary, his paramount concern in this regard was to re-introduce into the teaching of the Catholic Church a spiritual element which is not specifically African, but valid for Christians of all nationalities. His ministry was for all who believed themselves in need of healing, regardless of region, nation or social class.

\section{Healing and gender}

It was also aimed at both men and wornen, atthough many eye-witnesses have recalled the particularly high number of women, who, possessed by spirits, fell into fits or trances, spoke in tongues, and showed other manifestations of ecstatic behaviour during the healing sessions. Some observers have suggested that Milingo specialized in healing barren women and he himself has hinted that they may have formed a particularly important element among his patients. In January 1979, for example, Archbishop Milingo wrote to a correspondent in Malawi: ' $I$ 'm dealing with thousands of women, and their problems are triple their number'. ${ }^{21}$ It appears incontestable that, at least in public, women were by far the most noticeable and probably the most numerous of Milingo's petitioners.

It is surprising, therefore, that about half the letters in our sample of 250 were written by men, some of whom explicitly state that they believe themselves to be possessed by evil spirits. Hence the documentary evidence appears at first sight to contradict the testimony of observers regarding the relative incidence of spirit possession among women and men. There are various explanations for the differences between documentary and oral evidence in this regard. One is that women in Zambia are traditionally expected to display more spectacular symptoms of spirit possession than are men. An obvious sociological explanation for this is related to the relative powerlessness of women in modern Zambia. There is little space, as it were, where women may express their views, their frustrations or their grievances other than through spirit possession. ${ }^{22}$

But the fact that possession is less easily visible among males does not mean that it is less frequent. In fact it seems that many non-Zambians

21. Letter from Milingo to Mrs B, Zomba (Malawi), 18 January 1979.

22. Lewis, Ecstatic Religion. 
misunderstand the nature of spirit possession, believing that it always takes a spectacular form. This is clearly not so. The letters of Milingo's correspondents show that many Zambians believe that spirit possession may last for an extraordinarily long time, 30 years or more, and may be marked by quite unspectacular symptoms, especially in men. One man, writing in 1980 , states that he has been possessed by evil spirits since 1966. ${ }^{23}$ Another case is still more long-lasting, when a father of six children writes that 'my mother ... has been possessed for as long as I have known her i.e. since my childhood and I am forty years old'. ${ }^{24}$

So unspectacular may be the symptoms of possession that several correspondents realise that they are possessed only after several years of suffering. Thus a male university graduate explains that 'I am a Christian who has been sick for years (although I did not know until recently)'. ${ }^{25}$ Spirit possession is not only a brief, intense experience occurring chiefly in women. It may last for years, is likely to affect both men and women, and is marked by a variety of symptoms. The evidence drawn from the letters to Milingo suggests that all who believe in spirit possession are potential sufferers, and that actual manifestations may not be visible to the naked eye, or even to the sufferer. ${ }^{26}$

The complaints of some men are clearly related to a modern urban environment and accordingly the surprisingly high number of male correspondents could indicate some sort of change in the incidence of spirit possession in recent years. Thus, men suffering from such typically modern ills as unemployment and lack of material success may believe themselves to be possessed. We may cite the case of an unemployed man unable to provide for his 11 children. 'I know I have been accompanied by evil spirits in all my undertakings', he writes, 'and I am therefore asking Your Grace to please chase them away'. ${ }^{27}$ Another unemployed man from the Copperbelt, aged 27, suffers from what a psychiatrist has diagnosed as 'anxiety and depression'. On 29 May 1980 he wrote to Milingo to seek his healing, having attended the Archbishop's public sessions since 1975. His poverty had caused him to remain unmarried. ${ }^{28}$ Poverty is also the main problem of a Catholic petitioner from Kabwe, who is unable to look after his children, his mother and grandmother. ${ }^{29}$ A young man from Matero township in Lusaka asks Milingo to discover the cause of his long-term unemployment and to heal his bad dreams and body pains. ${ }^{30}$

23. Letter to Milingo from N. M. M., Sinazeze, 26 May 1980.

24. Letter to Milingo from B. S., Kitwe, 30 June 1980.

25. Letter to Milingo from J. C., Lusaka, 15 July 1980.

26. A relevant theoretical distinction is that made by W, van Binsbergen, between permanent and momentary types of possession. Var Binsbergen, Religious Change, p. 105.

27. Letter to Milingo from J. E. S., Lusaka, 11 February 1980.

28. Letter to Milingo from $F$. M., Chililabombwe, 29 May 1980.

29. Letter to Milingo from F. M., Kabwe, 1 August 1980.

30. Letter to Milingo from A. M., Lusaka, 13 February 1980. 
Some male petitioners specifically complain of sexual problems for which they request healing from the Archbishop. In some cases these are undoubtedly the result of venereal disease. In others they probably have a psychological origin, which suggests that the pressures of modern urban life may cause men to fear impotence, which they attribute to evil spirits, in the same way as Zambian women have traditionally blamed evil spirits for their real or imagined barrenness. The letters reveal a fear of loss of sexual prowess on the part of some males, an aspect which has so far gone unnoticed in observations on Milingo's healing ministry. Perhaps the most striking such letter, dated 16 March 1979 , is from a man who has suffered from impotence since 1973 and been told by what he calls 'African witchdoctors' that he is suffering from evil spirits. He writes to Milingo: 'I am still suffering from these Evil Spirits which have rested in my chest for I fail to breath sometimes when I am asleep. Again they have rested in one of my testes which gives me pain every now and then. Your Grace, it has made me completely impotent for I do not satisfy my wife not even with a drop of sperm ${ }^{31}$ The correspondent thought this to be the reason his wife had not conceived for two years.

So men as well as women may believe themselves possessed. In fact, 23 letters of our sample concern women explicitly said to be suffering from possession by evil spirits, compared with 15 in which the victim is a man. Moreover, many letters which do not explicitly mention evil spirits are written in such terms as to make it clear that these writers, too, believe themselves possessed. All complaints commonly take a certain form and reveal certain characteristic symptoms of possession.

\section{The pathology of spirit possession}

Perhaps the commonest types of complaint made by Milingo's correspondents are physical ones, but of a rather special type. Very few of the 250 correspondents request healing for precise illnesses or ones with a selfevident cause, such as fractures, burns and so on. There are a great number of complaints of a vague nature like abdominal pain, backache, itching, dizziness, swollen legs and breathing problems. Other complaints do not cause physical pain but are nonetheless distressing. This category includes confusion and inability to concentrate, psycho-sexual problems, obsessive behaviour, flatulence and bad breath. In many cases sufferers complain of several such symptoms at the same time.

A good example of this is provided by a police detective writing on 28 May 1980. He claims he has been 'suffering or sick now for about eleven months'. He has sought various cures for his problems, which he attributes to possession by evil spirits. He continues:

31. Letter to Milingo from J. M., Mansa, 16 March 1979. 
During this period, I have been going to hospital but nothing helped me and then later I decided to use African medicine but these two types of medicine I have been using have not helped me. The problems I am facing are as follows: terrible continuous head pain, chest and waist pains, backache, and sometimes I find also my thinking affected . . . ${ }^{32}$

The detective's symptoms, vague as they are, could be caused by any one of a variety of illnesses. However, other complaints of a physical nature are more mysterious and hardly relate to any disease known to clinical medicine. One of the most striking such complaints is of a lump moving through the body. Thus a Catholic teacher from Kasama writes to describe how his wife suffers: 'She feels something like a caterpillar moving in her head and eating her bones; and as a resuit she even complains of a very strong smell which upsets her'. He goes on to describe this as 'a devilish magical illness'. ${ }^{33}$ A woman writing from Kitwe on 8 March 1979, a 44-year oid mother of seven, complains that she has had a similar moving lump for 14 years: 'It moves in my blood since 1965 when I woke up one morning feeling something in my gullet just like a shell of a nut'. ${ }^{34}$ Since then the feeling has passed all over her body, and consultations with both clinical and traditional healers had failed.

In many cases, petitioners specifically attribute these vague symptoms to possession by evil spirits which they refer to by a variety of names. Sometimes they are referred to by African names such as ngulu, mashave and vibanda, but more often by the vague English term 'evil spirits', and occasionaily by specifically Christian appellations such as Lucifer, Satan or the Devil. In any event, correspondents believe that symptoms like those listed above, whether physical or not, are typical of spirit possession. In only a few cases do correspondents mention some portent of spirit possession. One writer, for example, says that he knows his aunt is possessed because a black cock keeps entering her house and crowing. ${ }^{35}$ Another, the same policeman who had complained of physical pains, appears to suspect ancestral influence. He writes: 'I had an uncle who was suffering from Evil Spirits but now he is dead. To my surprise, I find myself singing the type of songs my late uncle was singing whenever he was possessed and last year when I was taken home for treatment, I found myself sometimes singing as well as dancing in the same way as my late uncle was doing'. ${ }^{36}$

At least five correspondents refer in detail to dreams which cause them to believe they are possessed by spirits or otherwise in need of Milingo's healing. A seminary student believes an evil spirit to be the cause of a dream in which he made love to his own mother and which subsequently caused him

32. Letrer to Milingo from G. M. M., Mazabuka, 28 May 1980.

33. Letzer to Milingo from E. S., Kasama, 18 July 1980.

34. Letter to Milingo from Mrs. S. M., Kitwe, \& March 1979.

35. Letter to Milingo from M. C., Kabwe, 20 February 1979.

36. Letter to Milingo from G. M. M., Mazabuka, 28 May 1980. 
to become impotent. ${ }^{37}$ Other petitions are prompted by some predicament which, so the writers feel, can be caused only by evil spirits and can be cured perhaps by spiritual healing. We have already mentioned a number of male complaints, such as impotence. Similarly, many women complain of having suffered miscarriages, or of having had no children for several years, although often this is after they have already produced at least one child. One of the most worrying aspects of childlessness is its social consequences. It can lead to divorce, which is considered unchristian, and to family quarrels. 'What we badly need is a child', writes a father of one boy born four years previously. 'We have no peace of mind. Although I need a child my wife needs the child badly. She does not give me peace'. ${ }^{38}$ A traditional healer had attributed this state of affairs to the presence of evil spirits.

Just as childlessness, or, more often, insufficient numbers of children, can be seen as caused by evil spirits and can cause disharmony in the family, the fact of domestic strife in general can also be construed as having a spiritual cause. Such problems are frequent in the face of grinding poverty and the pressures of the extended family. A schoolgirl from a Lusaka township describes a not uncommon domestic story:

$I^{3} \mathrm{~m}$ the fifth born in a family of eight. Dad died in a car accident in 1977. Since Dad's death my sister [2nd born] who is married is the one who has been supporting me. My sister and him are like strangers. My brother-in-law stops talking to my sister for no reason. My brother-inlaw is the mean type. He doesn't like parting with money even if it means buying clothes for his own kids. He can sometimes sleep out when he feels like. To make matters worse my sister doesn't get much for her pay. So she finds it difficult to support me. Secondly I have a brother Charles [1st born]. He is a drunkard and doesn't care about the family. $^{39}$

In such poverty it is hardly surprising that there also exist disease, depression, misery and family feuds often caused by the presence in the household of a sister, a brother or a nephew who needs support.

The letters to Milingo leave little doubt that many Zambians, of all social classes, consider spirit possession to be a frequent cause of illness, misfortune, and social discord. They identify a pathology of possession. Physical symptoms commonly considered to be caused by spirit possession include many complaints with no obvious physical cause, and which could indeed be considered psychosomatic by a medical doctor. General aches

37. Letter to Milingo from G. G. C., Kabwe, 28 June 1980.

38. Letter to Milingo from V. P., Choma, no date.

39. Letter to Milingo from Miss M. C., Lusaka, 19 May 1980. 
and pains fall into this category. So does the mysterious sensation of a lump travelling round the body. Bad smells, lack of concentration, obsessive behaviour, impotence, infertility, social strife and disturbing dreams are also typical symptoms of spirit possession. Like all cause and effect, the process can be looked at from either side; just as a person who displays some of these symptoms may conclude that he must have been possessed by an evil spirit, so a person who believes that he has been visited by an evil spirit will start to display or imagine typical symptoms.

It appears that modern Zambians, like most people in the world, have a simple enough vision of the good life. In brief, it is that lived in material comfort surrounded by an abundant and contented family. But the ideal, which might stand some chance of realisation in a traditional village, is threatened on all sides in a modern Zambian city. Thus some petitioners complain of family quarrels provoked by the demand to support a nephew, a parent-in-law or other dependents who in a village might be expected to earn their keep by farm work, but who in town are just another drain on an insufficient income. Childbearing too poses different problems in town. Whereas it is still generally regarded as a blessing to have numerous children - and infertile women are therefore dishonoured for their failure to produce-children can also cause great strain on a poor family. In the same way polygamy, traditionally a desirable condition, is felt by some petitioners to be less so in town, where it is both expensive and reprehensible in the eyes of the Church and advanced sectors of society. For all these reasons, a traditional view of the good life is hard to sustain in town. The duties and taboos associated with the extended family can no longer be observed, and town-dwellers feel guilty in consequence. They explain the guilt as spirit possession. ${ }^{40}$

\section{The limits of traditional healing}

Many informants have told us that spirit possession, the consultation of traditional African healers and related practices have occurred since the 1960 s on a scale large enough that it is legitimate to speak of a revival. It appears plain that Archbishop Milingo was party to this revival in that he happened to be appointed to the see of Lusaka, with his particular gifts of spiritual healing, at a time when increasing numbers of people felt a need for such healing. To some extent he was also a cause of the revival in that he was a prince of the Church who offered a solution to peoples' spiritual needs in a way which no churchman had previously done. He thus attracted adherents from all Christian denominations and from none, in considerable numbers.

40. For an interesting discussion on the role of spirit possession in the process of social change, see J. M. Schoffelecrs, "Christ as the Medicine-man and the Medjcine-man as Christ", Man and Life, $8(1982)$, pp. 11-28. 
Clearly, it is necessary to consider why those who suffer from spirit possession have not been able to find a cure by traditional means, that is by recourse to an African traditional healer or nganga. Many correspondents state that they have had recourse to Milingo only after unsuccessfully seeking cures elsewhere. At least 23 letters out of 250 explicitly refer to unsuccessful visits to traditional healers, usually referred to as 'African doctors', 'African herbalists', nganga, or 'witch-doctors' by the correspondents.

According to descriptions written in the early 20th century, pre-colonial society in Zambia contained different categories of healers, all of whom could be included in the generic description of nganga. ${ }^{41}$ There were, for example, those who specialised in treatment of the sick by herbal remedies, and those skilled in exorcism. Individual healers might have reputations for ability in various types of cure. Moreover within the area of modern Zambia there existed in the past various types of spirit possession called by different names. As has already been mentioned, mashave are spirits originating among the Shona of Zimbabwe and they are most commonly found in eastern and southern Zambia. Ngulu were previously found chiefly among the Bemba. These and others like vibanda were all distinct types of spirit possession occurring in distinct localities, where local healers might be able to effect a cure.

It seems from the letters to Milingo that in modern Zambia these historical differences have been largely eroded to the extent that people writing to Milingo will refer to vibanda, ngulu, mashave (and for that matter Lucifer and the Devil) as though all were synonymous. A man writing from Lusaka on 9 June 1980 states that his brother is possessed by spirits which go under the names mizumu, mashabe [sic] or nzila. ${ }^{42}$ Until recently these three were all different types of possession. The same writer goes on to say that he himself suffers from an illness which passes from one part of his body to another. Some herbalists have informed him that this is caused by 'evil spirits'. Others that it is caused by what he terms 'black magic'. ${ }^{43}$ It seems that modern Zambians increasingly consider that there is only one type of spirit possession, although it may be called by different names depending upon which language one is speaking or from what part of the country one originates. This is, of course, the belief of Christians, and notably of Archbishop Milingo himself, for whom all evil proceeds from the Devil and in whose view all evil may be healed by one all-powerful spirit, the Holy Spirit. In passing, we may note that the apparent erosion of beliefs in distinctive local spirits, and their incorporation into a nationwide or worldwide phenomenon of possession, constitutes an enlargement of scale 41. For a description of the different rales and the 'art' of nganga, sce J. M. Janzen, The Quest for Therapy in Lozver Zaire (University of California Press, Berkeley, 1978).

42. Letter to Milingo from G. M. K., Lusaka, 9 June 1980 .

43. Letter to Milingo from G. M. K., Lusaka, 9 June 1980. 
paralleled by national government and universal religion. The assimilation of local spirit cults into one, going under a variety of names, is in itself a modern trend in Zambia. ${ }^{44}$

Thus, one explanation for the failure of old-fashioned nganga is that they are less well-equipped than a Catholic churchman to deal with a modern phenomenon, that of universal spirit possession. This view is reinforced by what Zambians of different professions and backgrounds have told us about modern healers. There is a quite widespread view that healers operating in large towns are nothing more than herbalists, who are not really competent to exorcise spirits. ${ }^{45}$ This more esoteric skill is felt to be exercised more by rural healers whose knowledge is passed on from father to son. A healer living in a large township on the Copperbelt confirmed this in that he explained that the skills of herbalism could be quite easily learned, whereas the knowledge of spirits was rarer and passed from generation to generation in families skilled in the art. Other people have told us that a true spiritual healer, as opposed to a herbalist, is known by reputation and does not advertise his or her services. Hence a town-dweller who believes himself possessed may find that the nearest healer is a herbalist only, who does not claim any expertise in exorcism. True spiritual healers are said to be found rather in the villages, where the art is still alive. But, paradoxically, the village healers are specialists in the treatment of types of possession which are old-fashioned and do not relate to modern problems of unemployment, career worries and so on.

The opinion that many modern nganga are lacking in expertise is reinforced by the quite widespread opinion that the profession, if it can be called such, has been invaded by charlatans in recent decades. We have heard several stories of adventurers or failed businessmen setting themsclves up as healers after little or no training and advertising their services. One of the letters to Milingo describes the type quite well. A 50-year-old man suffering from chest pains, ulcers and bad breath for 30 years writes how, in 1979, he sought the help of "one of the Magicians, Dr Dooh Nkandu, who is a traditional spiritual healer. I contacted this man at Lusaka InterContinental Hotel and paid Io kwachas in Cash for medicine. When I was examined he told me to pay a sum of 200 kwachas if I wanted treatment'. ${ }^{46}$ Even now this is a substantial sum, representing over a month's wages for a

44. Cf. R. Horton, 'African Traditional Thought and Western Science', Africa, 37 (1967), pp. 50-72, 155-188; also Schoffeleers, Christ as the Medicine-man, p. 21.

45. Avaikable data concerning Lusaka suggest that the use of herbs forms a major eiement in treatment by most nganga but that many of them also consider themselves specialists in the treatment of spirit possession. See R. Frankenberg \& J. Leeson, 'Disease, Iliness and Sickness: social aspects of the choice of healer in a Lusaka suburb', in J.B. Loudon, Social Anthropology and Medicine (L.ndon, 1976). This was confirmed by oral information from the Ministry of Health which suggested that most craditional healers combine several skills. The traditional way of healing possession, which is through a dancing ceremony, is still practised by some healers, especially in the poorer townships of Lusaka.

46. Letter to Milingo from F. M., Luanshya, 30 May 1980. 
manual worker. Furthermore, there has been considerable price inflation since 1979. Archbishop Milingo charged no fee, which is not only attractive but is widely felt to be a sign of probity in a healer, who should properly charge a fee only after successful treatment.

Other letters refer to the difficulty of obtaining expert advice on healing. The leader of a Catholic charismatic group with which Milingo had been associated wrote to the Archbishop in 1980 imploring him to take part in the group's work of casting out evil spirits. ${ }^{47}$ The chairman of a church council in Lukwesa writes to say that he knows of people who believe they have been given healing powers by the Holy Spirit. On behalf of these people he requests the Archbishop to visit the parish and advise them on how to go about utilizing these gifts they have been given'. ${ }^{48}$ Some correspondents mention that they have been healed by individual Catholic priests, and others say they would like to visit a nganga but would prefer Christian healing. All implore Milingo to use his gifts in the service of the sick. All these letters reinforce the view that there exists in Zambia a perception that spiritual healing is necessary but that competent or qualified healers are rare. Milingo, therefore, satisfied a vast demand during the years that he was healing the sick.

\section{The politics of possession}

The evidence that large numbers of Zambians, including town-dwellers, believe in the reality of spirit possession, and attribute their misfortunes or ills to it, has profound political implications. It suggests that many of Zambia's high number of town dwellers have retained the substance of traditional beliefs which are sometimes misleadingly said to belong to the village and to the vanishing past. It is neither new nor surprising to make this observation, since it has often been noted that urban Africans retain important elements of traditional culture to serve new purposes in the context of new pressures.

If, as so many observers have suggested to us, Zambian society has been subject to a considerable spiritual revival since the early or mid-1970s, it is interesting to consider what the causes and implications might be. Some informants suggest that the phenomenon is associated especially with povercy. Without doubt, this is a persuasive argument which is borne out by many of the petitions to Archbishop Milingo in 1979-80. Every available statistic, as well as the subjective verdict of Zambians, is that the country as a whole has grown poorer since the early 1970s. The causes for this include the high rate of population growth, the lack of successful

47. Letter to Milingo from J. Z., Lusaka, 12 March 1980

48. Letter to Milingo from N. P., Lukwesa, 2 July 1980. 
government policies on crop production and marketing, the increase in world oil prices, and the impact of political crises in Rhodesia and South Africa. Above all, Zambia, which depends so hugely on its production of copper, has suffered from the fall in world commodity prices since 1974 . There is surely a link between poverty and spirit possession. Both the letters to Milingo and other evidence suggest that possession by an evil spirit is often seen as a symptom of poverty and, in instances where spirit possession leads to ecstatic behaviour, it itself provides an emotional release from the suffering of the poor ${ }^{49}$

However, poverty is not the only cause of the revival of spirit possession Zambia remains a deeply religious society in a way which would probably surprise some of those who observed or campaigned for independence in 1964. The independence movement started really only in the 1950 s among forward-looking people, themselves schooled to some extent in the European tradition of statecraft. They came to inherit, through political parties based on foreign models, the apparatus of the colonial state. No one has recognized this more clearly than President Kaunda himself, who in his philosophy of Humanism has attempted to define how village principles of solidarity and cooperation can be harnessed to a modern political structure. Humanism was intended not only as a guide to political action by workers of the ruling United National Independence Party (UNIP) but also as the philosophy of old Africa updated, which could provide an ideology for the government of independent Zambia. The struggle for independence was deeply popular, in Zambia as elsewhere in Africa. Thousands of peasants and townspeople, including wage-labourers and even the unemployed, used to attend party meetings, campaign for independence and give their active support to UNIP. It promised a better world for all Zambians in which they would be free and prosperous. They would govern themselves and society would be fundamentally harmonious in a way that colonial society by its very nature could never be.

Although UNIP did not address itself specifically to the spiritual needs of the people, it nevertheless offered a programme which was spiritually reassuring in that it promised social harmony. There is evidence, to judge from the fervour inspired by UNIP rallies in the early 1960s, that Kenneth. Kaunda was seen almost as a spiritual leader. For, while neither UNIP nor the modern state apparatus are equipped to heal other than by providing order and harmony on a national scale, President Kaunda himself often uses a quasi-religious rhetoric and speaks of the need for peace and unity in society.

Traditionally, just as good health and harmony are the signs of well-being in an individual or family, so they are in society at large. The letters 
to Milingo confirm an observation frequently made of African culture in general, namely that Africans commonly view mental, physical and social health as an integral whole. ${ }^{50}$ A dysfunction in one aspect of the person or personality affects the whole. The same appears to be true at the national level, where controversy in the religious sphere has an inevitable political dimension. As the letters to Archbishop Milingo indicate, modern Zambians show little sign of abandoning the traditional belief in the pervasive influence of the spirit world or of regarding this as incompatible with modern life. They continue to believe that failures in health and harmony at either the individual or social level are symptoms of the presence of evil spirits. Evil is that which harms the health of the individual and his or her relationship to society. Accordingly, the spiritual revival which is said to have started in the early or mid 1970s and which was closely associated with Milingo's healing until his departure from Zambia in I 982 is caused by factors less tangible than simple poverty. One such factor is that independence has not brought harmony to every group in society. Social life in the industrial towns is increasingly difficult and violent. The traditional support of the extended family, which has always been considered the foundation of village life, can either break down in towns or cause resentment since it can lead to parasitism for a wage-earner. In either case it represents a breakdown which can cause people to feel guilty. Another consideration is that UNIP has ceased to reassure in the way it did in the early $1960 \mathrm{~s}$, when it took power and offered so muck. Its meetings are poorly attended. It has become little more than an arm of the state bureaucracy.

Like most or all African cultures, Zambians in the past have made no distinction between politics and religion. In the history of the peoples who inhabit modern Zambia, political authority is founded on religion and statecraft and is often exercised through symbols or rites charged with religious meaning. A body politic, to be legitimate, had to be endowed with supernatural authority. This was one reason why the colonial regime never really was legitimate, since it made no convincing attempt to fulfil the religious role which Zambians expected of governments they had previously known. And while the nationalist politicians of the independence movement, being Zambian, were aware of this tradition, they made at least two assumptions or calculations which have been proved wrong in time. The first was that independence would provide government with a new principle of legitimacy, as great as that accorded to the ancestors. The second was that modernity and development would rapidly erode some African beliefs which seemed archaic. These included both the belief in spirit possession at the individual level and in the spiritual or religious aspect of political life in general.

50. See e.g. J. S. Mbiri, African Religions and Philosophy (Heinemann, London 5 th edn. 1975); also E. Milingo, The Demarcations (Teresianum Press, Lusaka, 1982), pp. 100-107. 
Spirit possession is widespread in modern Zambia. It is related to economic and social problems of great seriousness and, indeed, may be caused by them in part. ${ }^{51}$ This phenomenon must worry politicians. Yet there is no evidence that any of Milingo's petitioners believes that Zambia has been possessed in the way that an individual or family might be. Nor does Milingo himself believe the Zambian nation or the Zambian state as such to be possessed, only a mass of individuals. One may object that this distinction is mere pedantry, and that, if sufficient numbers of Zambians are possessed by evil spirits, then it is tantamount to saying that the Zambian nation is possessed. However, we believe the distinction between the mass of Zambians and the Zambian nation is a valid one, which goes to the heart of an African political tradition.

So, while in theory an evil spirit could possess anyone or any institution which inhabits the Zambian spiritual landscape, there is no evidence that anyone believes the nation to have been possessed. Possibly this is a tribute to the continuing authority, still expressed in terms with religious connotations, of President Kaunda, the founding father of the nation. However, a more convincing explanation is that the traditional expressions of spirituality, while they are believed to operate at the level of the family or neighbourhood, are not believed to do so at the level of the Zambian nation. In other words, the Zambian nation, as opposed to a mass of individual Zambians, does not have a place in the spiritual landscape. This is not surprising in that the idea of a Zambian nation is a modern one, introduced in the 1950 s by foreign-educated intellectuals in imitation of a European secular model. Evidence from other parts of Africa which had sophisticated states and an authentic and truly popular concept of nationhood in precolonial times suggests that it is possible for an entire nation to become possessed. ${ }^{52}$

One might say that, given the Zambian or even African tradition of politics and its relation to the spirit world, only when Zambians are truly convinced of their own nationhood will the nation be capable of possession. To put it the other way round, if ever Zambians feel their nation to be possessed, that will be a sign that Zambians have truly assimilated the idea of a nation and have made it an authentically Zambian concept. To be legitimate, a political institution must have a place in the spiritual landscape. Hence, the social crisis represented by mass possession does not, in present circumstances, imply a political crisis, although Zambia's economic decline has certainly entailed political pressures. The state still, 23 years after independence, is not fully integrated with the society it governs. Its relative autonomy from society is a consequence of its foreign origin.

51. Lewis, Ecstatic Religion. For a discussion of the deprivation theory, see van Binsbergen, Religious Change, pp. 100-102.

52. F. Raison, 'Les Ramanenjana', Asie du Sud-Est et le Monde Instindien, 7 (1976), pp. 271-293. 


\section{Conclusion}

The growth of spirit possession and related phenomenon in Zambia in recent years can be said to indicate a failure of both Church and state. The state's highest level of authority, the national government, seems itself reluctant to acknowledge the existence of spirit possession or to offer a remedy for it. Even the Church, a proper agency for spiritual affairs in modern political practice, has refused to recognize the phenomenon except when Archbishop Milingo occupied the see of Lusaka. The Milingo affair indicates that the Church itself, which enjoys good relations with the government for the most part, is not perfectly equipped to deal with popular spiritual needs. The case of Milingo shows that the Church does have the potential to deal with these, but is unwilling to do so because of the problems it poses in both the theological and political spheres. Since Milingo's removal from Lusaka in 1982, peoples' deepest spiritual needs have therefore gone unattended, although the government has made increasing recognition of the role of nganga. ${ }^{53}$ The Church in Zambia, too, is of non-African origin, like the modern state, and it still bears traces of that. While millions of Zambians are devout Christians, their views on spirits and healing fall outside the scope of both state and Church, which are essentially collaborators in matters of power. The government sometimes finds it convenient to associate itself with the Church, in order to give itself an aura of supernatural authority, while at other times it finds it convenient to invoke the separation of Church and state, as in the case of Milingo's removal.

In these circumstances modern Zambians who believe themselves possessed by evil spirits have only a restricted possibility of healing. If they do not want to visit a nganga, they may find a local priest who, in spite of the view of the Catholic hierarchy, is willing to exorcise a spirit. Or they may attend the meetings of a charismatic group or frequent an independent church which gives more scope to spiritual healing and related expressions of spirituality. We suspect that this was a powerful attraction of the Watchtower movement which flourished during the colonial period and of the Lumpa Church which prospered from about 1954 to 1964 . Both movements were treated with suspicion and even repressed by the government of the day because of their political implications. ${ }^{54}$ And, while Archbishop Milingo eschewed politics and was a member of a highly disciplined church, his movement too had political undertones by the sheer number and enthusiasm of his supporters. Just as the colonial government could not permit a movement of African autonomy in the spiritual sphere, so the present

53. After the first national workshop on traditional medicine held in Lusaka in 1977, a special unit was formed in 1983 within the Ministry of Health. Among other things this unit set up the Traditional Health Practitioners Association of Zambia. The unit distinguishes four categories of healers: herbalists, faith healers, spiritualists, and traditional birth attendants.

54. A. D. Roberts, $A$ History of Zambia (Heinemann, London, London, 3rd edn., 1981), pp. 199-200, 221, 250. On the Watchtower movement, K. E. Fields, Revival and Rebellion in Colonial Central Africa (Princeton University Press, Princeton, 1985 ). 
government must treat with caution a modern spiritual movement. In any case neither Church nor state feels competent or confident enough to put itself at the service of the people in these spiritual matters. The modern state, erected in colonial times on a foreign and secular model, is unequipped to deal with spirit possession. The Church, though also introduced in the modern period and being based on a foreign model, has the potential to deal with it but refuses to do so. 